\title{
MENINGKATKAN SIKAP TANGGUNG JAWAB DAN PRESTASI BELAJAR MELALUI MODEL PEMBELAJARAN TIPE NUMBER HEAD TOGETHER (NHT) BERBANTU VIDEO STOP MOTION
}

\author{
Meilyyana Cahya Pramestika ${ }^{1}$, Arifin Muslim², Karma Iswasta Eka ${ }^{3}$ \\ ${ }^{1}$ Mahasiswa Program Studi PGSD Universitas Muhammadiyah Purwokerto \\ ${ }^{2,3}$ Dosen PGSD Universitas Muhammadiyah Purwokerto \\ 1'cahya.pramestika@gmail.com, ${ }^{2}$ arifinmuslim@ump.ac.id, ${ }^{3}$ eka2001id@gmail.com
}

\begin{abstract}
The background of this research is a phenomenon of the low of students' responsibility attitude and learning achievement. The research is aimed to improve students' responsibility attitude and learning achievement through learning model number head together (NHT) with stop motion video. The class action research was consisting of planning, implementation, observation and reflection steps. The subjects of this research were on sixth grade students of elementary school Susukan, with the total numbers were 24 students. The research instruments used were evaluation test, observation sheet and questionnaire. The finding showed there was an improvement of each cycle. The result of this research showed that the using of the learning model numbered head together (NHT) could improve student' responsibility attitude and learning achievement in theme 9 "Kayanya Negeriku" on the sixth grade students of elementary school Susukan, Wanayasa district, Banjarnegera.

Keywords: Responsibility' Manner, Learning Achievement, Numbered Head Together (NHT)
\end{abstract}

\begin{abstract}
Abstrak: Penelitian ini dilatar belakangi oleh rendahnya sikap tanggung jawab dan prestasi belajar peserta didik. Penelitian ini bertujuan meningkatkan sikap tanggung jawab dan prestasi belajar melalui model pembelajaran Numbered Head Together (NHT) berbantu video stop motion. Penelitian tindakan kelas terdiri dari tahapan perencanaan, pelaksanaan, observasi dan refleksi. Subjek penelitian adalah peserta didik kelas IV SDN Susukan, berjumlah 24 peserta didik. Alat pengumpulan data menggunakan tes evaluasi, lembar observasi dan angket. Hasil penelitian menunjukan peningkatan disetiap siklus. Hasil penelitian ini menunjukan bahwa penggunaan model pembelajaran Numbered Head Together (NHT) dapat meningkatkan sikap tanggung jawab dan prestasi belajar pada tema 9 Kayanya Negeriku di Kelas IV SDN Susukan, Kecamatan Wanayasa, Banjarnegara.

Kata Kunci: Sikap Tanggung Jawab; Prestasi Belajar; Numbered Head Together (NHT)
\end{abstract}

endidikan merupakan hal yang
penting bagi setiap manusia.

Pendidikan pada dasarnya dilaksanakan untuk mencapai tujuan dalam pendidikan.Tujuan pendidikan memuat gambaran mengenai nilai-nilai yang baik, luhur, benar, pantas, dan indah untuk kehidupan.

$$
\text { Perlu adanya perubahan atau }
$$
peningkatan mutu pada pelaksanaan sistem 
pendidikan agar tujuan pendidikan nasional dapat tercapai dengan baik. Salah satunya adalah dengan melakukan perubahan maupun perbaikan pada kurikulum pendidikan yang ada. Mulyasa (Hidayati, 2015:2) mengungkapkan bahwa "Diperlukan sebuah perubahan yang cukup mendasar di dalam sistem pendidikan nasional, yang dipandang oleh berbagai pihak sudah tidak efektif. Perubahan mendasar tersebut berkaitan dengan kurikulum, yang dengan sendirinya menuntut dan mempersyaratkan berbagai perubahan pada komponen-komponen pendidikan lain".

Kurikulum 2013 adalah kurikulum yang masih diterapkan di dunia pendidikan di Indonesia sampai sekarang sebagai pengganti dari kurikulum KTSP. Yusuf (2018:272) mengungkapkan bahwa "Kurikulum 2013 merupakan perangkat mata pelajaran dan program pendidikan dengan sistem dimana siswa lebih aktif dalam kegiatan belajar mengajar yang menitikberatkan untuk mendorong siswa agar lebih baik dalam melakukan observasi, bertanya, bernalar, dan mempresentasikan apa yang mereka peroleh atau mereka ketahui setelah meneerima materi pembelajaran". Berbeda dengan kurikulum sebelumnya, kurikulum 2013 lebih menekankan pada ketiga aspek, yaitu afektif, psikomotorik, dan kognitif yang berkesinambungan. Sehingga diharapkan agar siswa lebih kreatif, inovatif dan lebih produktif.

Berdasarkan hasil observasi yang dilakukan di kelas IV di SD Negeri Susukan dalam proses pembelajaran berlangsung peneliti menemukan permasalahan seperti pada saat kegiatan pembelajaran belum berjalan dengan baik. Hal ini dapat dilihat pada saat kegiatan pembelajaran berlangsung, ada beberapa peserta didik yang tidak memperhatikan dan suka mengobrol dengan teman sebangku. Guru juga menjelaskan bahwa beberapa peserta didik sering lupa untuk mengerjakan tugas, tidak mau menjawab ketika ditunjuk guru, peserta didik masih suka mencontek, dan pada saat diberikan tugas secara berkelompok, peserta didik masihcenderung mengandalkan teman sekelompoknya.Bahkan seringkali ditemui peserta didik yang makan di saat kegitan pembelajaran berlangsung. Hal ini membuktikan bahwa tingkat sikap rasa tanggung jawab peserta didik masih tergolong rendah.

Permasalahan lain yang ditemui oleh guru kelas IV SDN Susukan adalah masih rendahnya nilai UTS yang diperoleh peserta didik. Guru menyatakan bahwa nilai UTS IPA dan Bahasa Indonesia yang diperoleh peserta didik sebagian besar belum memenuhi KKM yang ditentukan oleh sekolah. Hal ini merupakan indikasi 
bahwa prestasi belajar peserta didik masih tergolong rendah.

Permasalahan sikap tanggung jawab dan prestasi belajar peserta didik kelas IV SD Negeri Susukan diperoleh solusi yaitu menggunakan model dan media pembelajaran. Peneliti ingin menggunakan model pembelajaran kooperatif tipe NHT berbantu video stop motion untuk meningkatkan sikap tanggung jawab dan prestasi belajar peserta didik.

Model pembelajaran kooperatif tipe NHT lebih mengedepankan kepada interaksi peserta didik dalam kegiatan pembelajaran. Vitoria \& Akhwilla (2018:12) mengungkapkan bahwa model pembelajaran NHT merupakan model pembelajaran kooperatif yang menuntut semua anggota kelompok untuk memahami materi agar dapat menyelesaikan tugas yang diberikan oleh guru dan mampu mempresentasikan hasil diskusi.Pada praktiknya, model pembelajaran ini dapat melatih sikap tanggung jawab peserta didik melalui sistem kerja kelompok, masing-masing peserta didik akan mendapatkan tugas dan akan saling bekerja sama dalam mencari, mengolah, dan menyusun jawaban maupun materi dari tugas yang diberikan oleh guru, kemudian dipresentasikan di depan kelas.

Model pembelajaran dapat dikombinasikan dengan media pembelajaran sebagai pendukung guru dalam melaksanakan kegiatan pembelajaran. Salah satu bentuk media pembelajaran yang dapat diterapkan adalah media berbentuk video pembelajaran dengan konsep stop motion.Wijayanto (Qamariah, $\quad$ dkk, 2017:268) mengemukakan bahwa stop motion merupakan suatu metode pembuatan animasi tradisional. Metode pembuatan stop motion ini menggunakan teknik fotografi untuk pengambilan objek gambar.

Berdasarkan permasalahanpermasalahan diatas, peneliti termotivasi untuk melakukan penelitian dengan menggunakan model pembelajaran NHT berbantu video stop motion di kelas IV Sekolah Dasar dengan judul penelitian "Upaya Meningkatkan Sikap Tanggung Jawab Dan Prestasi Pada Pembelajaran Tema 9 Kayanya Negeriku Melalui Model Pembelajaran Tipe NHT berbantu Video Stop Motion di Kelas IV Sekolah Dasar". Diharapkan model pembelajaran NHT berbantu video stop motion dapat meningkatkan sikap tanggung jawab dan prestasi belajar peserta didik di Sekolah Dasar.

Perumusan masalah pada penelitian ini yaitu "Apakah model model pembelajaran kooperatif tipe NHT berbantu video stop motion dapat meningkatkan sikap tanggung jawab dan prestasi belajar peserta didik pada tema 9 
Kayanya Negeriku di kelas IV Sekolah Dasar?".

Tujuan penelitian yang ingin dicapai adalah mengkaji secara mendalam peningkatan sikap tanggung jawab dan prestasi belajar peserta didik pada pembelajaran tema 9 Kayanya Negeriku melalui model pembelajaran kooperatif tipe NHT berbantu video stop motion di kelas IV Sekolah Dasar.

\section{METODOLOGI PENELITIAN}

Penelitian ini dilaksanakan di kelas IV SD Negeri Susukan pada semester II Tahun Ajaran 2018/2019. Subjek penelitian adalah peserta didik kelas IV berjumlah 24 peserta didik yang terdiri dari 14 peserta didik laki-laki dan 10 peserta didik perempuan.

Penelitian ini menggunakan prosedur Penelitian Tindakan Kelas. Penelitian tindakan kelas digunakan sebagai penelitian, karena PTK diharapkan dapat meningkatkan sikap tanggung jawab peserta didik dan dapat meningkatkan prestasi belajar peserta didik. Penelitian ini dilakukan dalam dua siklus tetapi jika dalam penelitian penelitian siklus II belum berhasil akan dilanjutkan siklus berikutnya. Model penelitian tindakan kelas yang digunakan adalah model Kemmis dan Mc.Taggart. Model ini memiliki empat tahapan yaitu perencanaan (planning), pelaksanaan (acting), pengamatan (observing), dan refleksi
(reflecting).Prosedur penelitian dapat digambarkan sebagai berikut:1)Perencanaan (Planning): pada tahap ini merupakan langkah awal yang harus dilakukan sebelum melaksanakan PTK, 2)Tindakan (acting): pada tahap inikegiatan yang dilakukan oleh guru atau peneliti sebagai upaya perbaikan, peningkatan, atau perubahan yang diinginkan, 3)Pengamatan (Observation): pada tahap inipengamatan dilakukan oleh dua pengamat dengan lembar pengamatan yang digunakan untuk mengamati kegiatan guru dan peserta didik pada saat kegiatan pembelajaran berlangsung.4)Refleksi (Reflection): pada tahap ini, akan digunakan sebagai bahan refleksi guna memperbaiki tindakan pada siklus berikutnya. Alat pengumpulan data menggunakan tes evaluasi, lembar observasi aktivitas guru, lembar aktivitas peserta didik, lembar observasi sikap tanggung jawab peserta didik dan angket sikap tanggung jawab peserta didik dan dokumentasi.

\section{HASIL PENELITIAN}

Hasil penelitian ini menemukan bahwa terdapat peningkatan sikap tanggung jawab dan prestasi belajar peserta didik melalui model NHT berbantu video stop motion. Peningkatan hasil sikap tanggung jawab dapat dilihat pada tabel 1 dibawah ini: 
Tabel 1. Hasil Angket Sikap Tanggung Jawab

\begin{tabular}{ccc}
\hline Siklus & Skor Rata-rata & Kriteria \\
\hline Siklus I & 4,04 & Baik \\
Siklus II & 4,30 & Sangat Baik \\
\hline
\end{tabular}

Berdasarkan hasil tabel 1 diatas menunjukan bahwa siklus I diperoleh ratarata 4,04 dengan kriteria baik. Hasil angket sikap tanggung jawab peserta didik pada siklus II diperoleh rata-rata 4,30 dengan kriteria sangat baik. Terjadi peningkatan yang baik pada tiap indikator. Hasil tersebut diperkuat dengan hasil observasi sikap tanggung jawab peserta didik kelas IV SD Negeri Susukan dapat dilihat pada tabel 2 berikut:

Tabel 2. Hasil Observasi Sikap Tanggung Jawab

\begin{tabular}{cccc}
\hline No. & Keterangan & Siklus I & Siklus II \\
\hline 1. & Jumlah Skor Keseluruhan & 58 & 72,5 \\
2. & Rata-rata & $60,37 \%$ & $75,51 \%$ \\
3. & Kriteria & Baik & Baik \\
\hline
\end{tabular}

Berdasarkan tabel 2 hasil observasi sikap tanggung jawab peserta didik dengan menerapkan model tipe NHT pada siklus I jumlah skor keseluruhan yang diperoleh adalah 58, rata-rata mencapai $60,37 \%$ dengan kriteria baik. Hasil pada siklus II jumlah skor keseluruhan yang diperoleh meningkat 72,5 rata-rata mencapai $75,51 \%$ dengan kriteria baik. Hasil dari pengamatan sikap tanggung jawab dapat dilihat pada saat pembelajaran berlangsung bahwa pada saat guru menjelaskan materi beberapa peserta didik memperhatikan penjelasan guru dan peserta didik berperan aktif dalam pembelajaran.

Peningkatan prestasi belajar peserta didik kelas IV SD Negeri Susukan dalam penelitian tindakan kelas yang dilakukan dalam dua siklus mengalami peningkatan. Prestasi belajar pada IPA dan Bahasa Indonesia berupa soal tes tertulis uarain dengan jumlah 5 butir soal.Hasil peningkatan prestasi belajar peserta didik dapat dilihat pada tabel 3 berikut:

Tabel 3 Hasil Prestasi Belajar IPA Peserta Didik

\begin{tabular}{clcc}
\hline No. & \multicolumn{1}{c}{ Keterangan } & Siklus I & Siklus II \\
\hline 1. & Nilai Tertinggi & 77 & 96 \\
2. & Nilai Terendah & 30 & 46 \\
3. & Jumlah Peserta didik & 24 & 24 \\
4. & Jumlah Nilai & 1429 & 1822 \\
5. & Peserta didik Tuntas Belajar & 13 & 21 \\
6. & Peserta didik Tidak Tuntas Belajar & 11 & 2 \\
7. & Rata-rata Nilai & 59,54 & 75,92 \\
8. & Presentase Ketuntasan & $54,16 \%$ & $87,58 \%$ \\
\hline
\end{tabular}


Tabel 4 Hasil Prestasi Belajar Bahasa Indonesia Peserta Didik

\begin{tabular}{clcc}
\hline No. & \multicolumn{1}{c}{ Keterangan } & Siklus I & Siklus II \\
\hline 1. & Nilai Tertinggi & 70 & 90 \\
2. & Nilai Terendah & 22 & 34 \\
3. & Jumlah Peserta didik & 24 & 24 \\
4. & Jumlah Nilai & 1120 & 1559 \\
5. & Peserta didik Tuntas Belajar & 9 & 19 \\
6. & Peserta didik Tidak Tuntas Belajar & 15 & 5 \\
7. & Rata-rata Nilai & 46,67 & 64,95 \\
8. & Presentase Ketuntasan & $37,5 \%$ & $79,16 \%$ \\
\hline
\end{tabular}

Prestasi belajar peserta didik mengalami peningkatan pada setiap siklus. Prestasi belajar IPA pada siklus I mencapai presentasi ketuntasnan klasikal sebesar $54,16 \%$ dan prsentase ketuntasan Bahasa Indonesia mencapai 37,5\%. Pada siklus II presentase ketuntasan IPA yang diperoleh adalah $87,58 \%$ dan Bahasa Indonesia meningkat menjadi $79,16 \%$.

\section{PEMBAHASAN}

\section{Peningkatan Hasil Sikap Tanggung Jawab}

Lembar angket sikap tanggung jawab digunakan untuk mengetahui peningkatan sikap tanggung jawab dimiliki peserta didik pada tema 9 Kayanya Negeriku melalui model pembelajaran tipe NHT. Peningkatan sikap tanggung jawab dapat dilihar pada gambar 1 berikut:

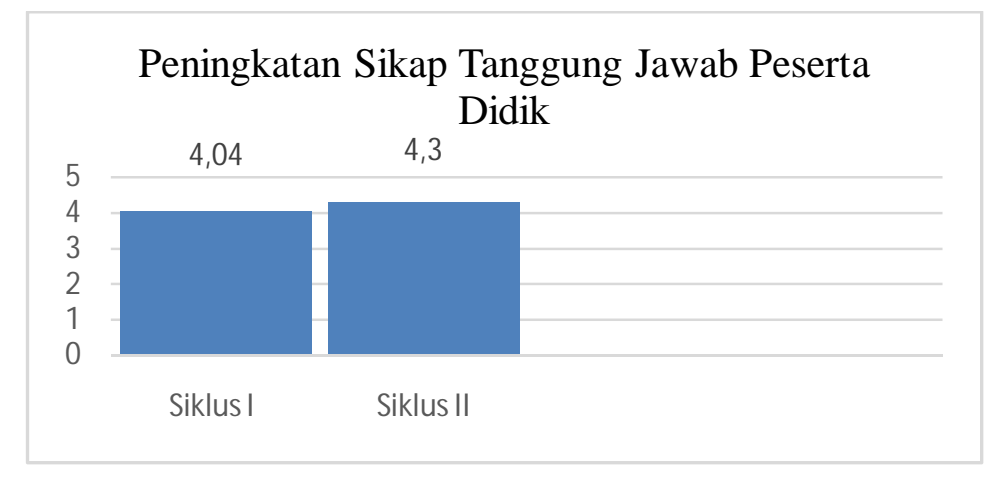

Gambar 1 Peningkatan SikapTanggung Jawab Peserta Didik

Gambar 1 histogram tersebut jelas adanya peningkatan dari skap tanggung jawab yang dimiliki peserta didik dari siklus I ke siklus II. Siklus satu rata-rata sikap tanggung jawab peserta didik menjapai 4,04 dengan kriteria baik dan meningkat menjadi 4,30 di siklus II dengan kriteria sangat baik. Berdasarkan hasil tersebut, menggunakan model pembelajaran tipe NHT berbantu video stop motion dapat meningkatkan sikap tanggung jawab peserta didik kelas IV SDN Susukan.

Pembelajaran tipe NHT memiliki peran penting dalam proses peningkatan sikap tanggung jawab peserta didik. Hal ini 
dapat dilihat dari beberapa tahapan pembelajaran yang berlangsung. Misalnya, pada saat tahap berpikir bersama dengan kelompok. Setiap anggota kelompok diwajibkan untuk dapat bekerja sama dengan baik untuk menentukan jawaban yang benar dari soal-soal yang harus dikerjakan oleh setiap anggota. Ketika salah satu anggota selesai mengerjakan soal yang menjadi tanggung jawabnya, maka kemudian seluruh anggota kelompok harus berdiskusi dan berpikir bersama untuk mengoreksi jawaban dari anggota tersebut. Pada tahap ini peserta didik akan dilatih untuk dapat bertanggung jawab terhadap tugas yang harus dikerjakannya, baik secara individu maupun berkelompok. Melalui kelompok belajar, tugas yang berat akan terasa lebih ringan karena dikerjakan secara bersama-sama. Pengetahuan, keterampilan dan kemampuan peserta didik akan meningkat karena di dalam kelompok belajar terjadi proses pertukaran pikiran antar individu. Werkani (Arfiah, 2017:269) menyatakan bahwa kelompok belajar adalah sebuah cara yang digunakan oleh dua orang atau lebih dalam mencari atau meningkatkan pengetahuan, keterampilan sikap atau kemampuan, peserta didik dalam satu kelompok dipandang sebagai suatu kesatuan tersendiri yang bersama-sama mencapai suatu tujuan pembelajaran dengan cara bergotong royong.
Tahap proses pembelajaran selanjutnya yang dapat meningkatkan sikap tanggung jawab peserta didik adalah tahapan ketika peserta didik ditunjuk oleh guru untuk membacakan jawaban di depan kelas. Setelah seluruh kelompok selesai mengerjakan soal pada LKPD, maka selanjutnya guru akan memanggil suatu nomor tertentu, kemudian peserta didik yang nomornya sesuai dengan nomor yang dipanggil oleh guru harus membacakan jawaban untuk seluruh kelas. Hal ini akan melatih dan meningkatkan keberanian serta sikap tanggung jawab peserta didik dalam menyampaikan pendapat di depan kelas.

LKPD digunakan oleh guru sebagai sarana untuk mengumpulkan data selama proses pembelajaran. Melalui LKPD, siswa akan dilatih untuk berperan aktif secara mandiri baik dalam kegiatan berkelompok maupun individu selama kegiatan pembelajaran. Sejalan dengan pendapat Sulastri (Novelia dkk, 2017:21) yang mengungkapkan bahwa "Lembar Kegiatan Peserta Didik (LKPD) adalah lembarlembar yang berisi tugas yang harus dikerjakan peserta didik untuk menguasai kompetensi yang dipersyaratkan. LKPD dapat dijadikan sebagai pedoman agar peserta didik dapat melakukan kegiatan pembelajaran secara aktif dan mandiri”. Berdasarkan hasil penelitan tersebut, maka peneliti dan guru bersepakat untuk memperbaiki kemampuan 
penguasaan kelas, melakukan tahap perencanaan dengan lebih matang agar peneliti, guru, dan peserta didik dapat melakukan kegiatan pembelajaran dengan lebih baik. Hasilnya pada siklus II terdapat peningkatan sikap tanggung jawab peserta didik dan prestasi peserta didik yang telah memenuhi indikator keberhasilan yang telah ditentukan. Keberhasilan dapat dilihat dari peningkatan nilai peserta didik maupun respon atau timbal balik yang baik dari peserta didik setelah melaksanakan pembelajaran NHT.

\section{Hasil Peningkatan Prestasi Belajar Peserta didik}

Hasil prestasi belajar peserta didik diperoleh dari hasil evaluasi individu pada setiap pertemuan di siklus I dan siklus II.Prestasi belajar peserta didik dengan menggunakan model pembelajaran tipe NHT berbantu video stop motion di kelas IV SD Negeri Susukan dikatakan meningkat. Peserta didik mampu menyerap materi yang dijelaskan guru dalam proses pembelajaran. Peningkatan prestasi belajar peserta didik dapat dilihat pada gambar 2 dan 3 berikut:

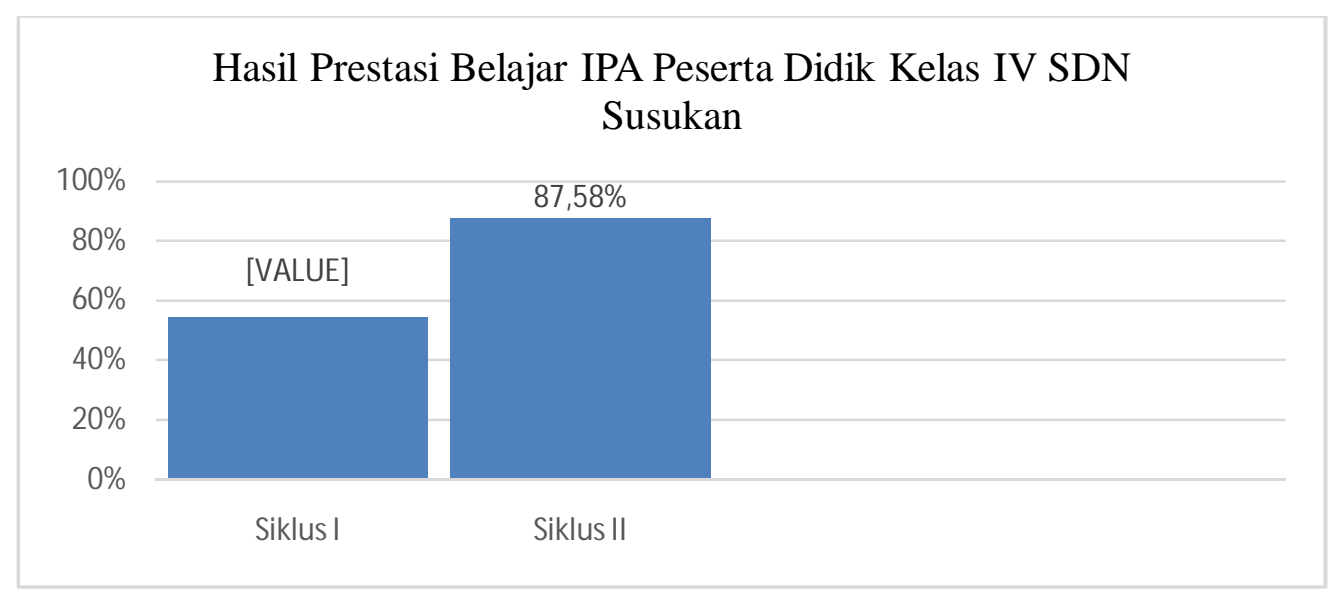

Gambar 2 Peningkatan Prestasi Belajar IPA Peserta didik Kelas IVSD Negeri Susukan 


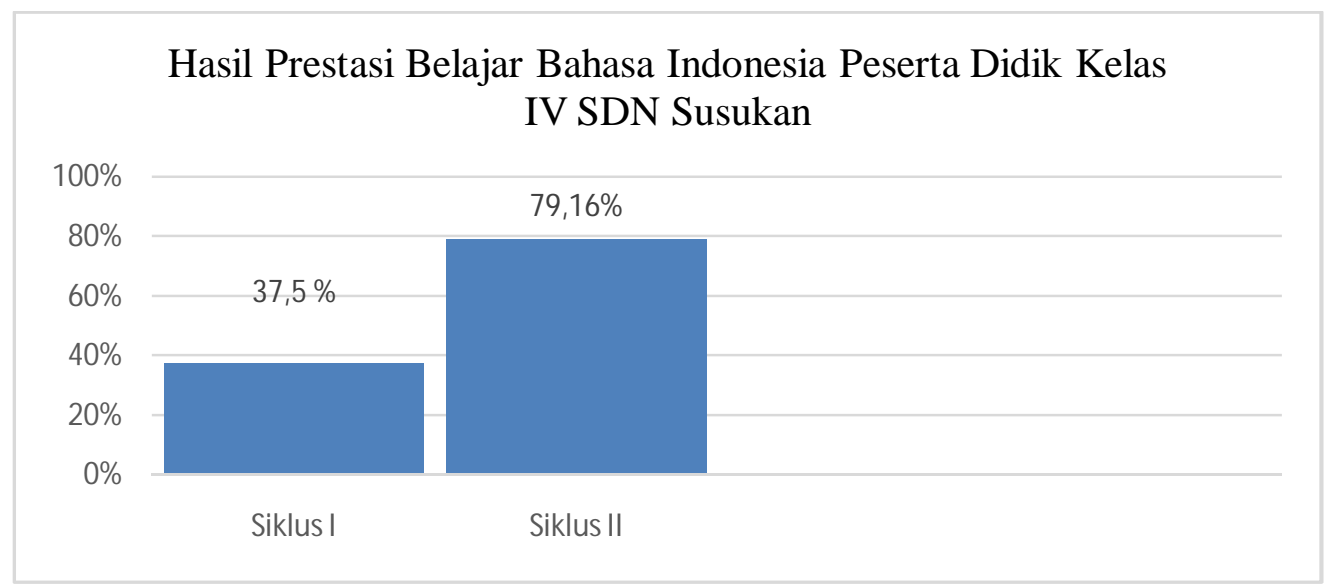

\section{Gambar 3Peningkatan Prestasi Belajar Bahasa Indonesia Peserta didik Kelas IVSD Negeri Susukan}

Berdasarkan histogram pada gambar 2 prestasi belajar IPA meningkat dari siklus I ke siklus II. Pada siklus I prestasi belajar peserta didik hanya mencapai $54,16 \%$ kemudian mengalami peningkatan pada siklus II menjadi $87,58 \%$. Pada gambar 3 histogram menunjukan bahawa prestasi belajar Bahasa Indonesia meningkat dari siklus I ke siklus II. Pada siklus I prestasi belajar peserta didik yang diperoleh adalah 37,5\%, kemudian mengalami peningkatan pada siklus II menjadi $79,16 \%$.

Peningkatan prestasi belajar tersebut dipengaruhi oleh tahapan-tahapan pembelajaran NHT dan peran dari media pembelajaran video stop motion. Salah satu tahap yang meningkatkan prestasi belajar peserta didik adalah tahap berpikir bersama dan tahap membimbing kelompok bekerja dan belajar. Pada tahapan ini guru mendampingi dan membimbing peserta didik di dalam kelompok agar dapat bekerja sama dengan baik. Apabila peserta didik dapat bekerja sama dengan baik, maka pertukaran informasi antar anggota kelompok akan semakin maksimal. Proses ini dapat memperkaya pengetahuan peserta didik dan memperdalam pengetahuan peserta didik akan materi yang dipelajari. Selain itu, peserta didik juga diberikan kesempatan untuk menanyakan secara langsung mengenai soal-soal atau materimateri yang kurang mereka pahami kepada guru.

Prestasi belajar dapat ditingkatkan melalui pembelajaran kooperatof yang diterapkan oleh guru. Pembelajaran kooperatif memungkinkan siswa dapat bekerja sama di dalam sebuah kelompok untuk menyelesaikan suatu permasalahan. Sejalan dengan pendapat Slavin (2009:4) bahwa "Pembelajaran kooperatif adalah pembelajaran yang merujuk pada berbagai macam metode pengajaran di mana para peserta didik bekerja dalam kelompok- 
kelompok kecil untuk saling membantu satu dengan lainnya dalam mempelajari materi pelajaran". Isjoni (2011:15) juga mengungkapkan pendapat yang sejenis yaitu bahwa "Model pembelajaran kooperatif (cooperative learning) adalah model pembelajaran dimana sistem belajar dan bekerja dalam kelompok-kelompok kecil yang berjumlah 4-6 orang secara kolaboratif sehingga dapat merangsang peserta didik lebih bergairah dalam belajar". Melalui kegiatan kerja sama dalam kelompok dapat meningkatkan ketertarikan, semangat, dan pemahaman peserta didik terhadap materi-materi yang dipelajari yang nantinya akan berdampak langsung kepada tingkat prestasi belajar peserta didik.

Peningkatan prestasi juga belajar dapat dipengaruhi oleh penggunaan media pembelajaran video stop motion yang menarik. Materi pembelajaran akan ditampilkan dalam bentuk video stop motion. Peserta didik duduk dengan tenang dan memperhatikan video yang diputarkan oleh guru, kemudian mencatat materi atau informasi penting yang terdapat di dalam video tersebut. Penggunaan media seperti ini akan meningkatkan ketertarikan peserta didik terhadap kegiatan pembelajaran. Selain itu, peserta didik juga akan mendapatkan pengalaman baru yang menyenangkan selama proses kegiatan pembelajaran berlangsung.
Peran guru dalam menerapkan model pembelajaran tipe NHT juga memberikan peningkatan pada prestasi belajar peserta didik. Penerapan model pembelajaran tipeNHT akan memberikan pengalaman belajar yang baik bagi peserta didik. Peserta didik dapat bertukar pikiran dengan teman-teman anggota kelompoknya, bersama-sama memecahkan dan menentukkan jawaban dari soal-soal yang diberikan oleh guru. Peserta didik terlihat sangat senang dan menikmati setiap proses dari kegiatan pembelajaran. Peningkatan sikap tanggung jawab dan prestasi peserta didik dipengaruhi oleh peningkatan aktivitas guru dalam menerapkan model pembelajaran tipe NHT.Adanya peningkatan aktifitas guru yang baik juga akan berdampak kepada meningkatnya aktifitas peserta didik. Peningkatan aktfitas peserta didik juga berkaitan dengan meningkatnya sikap tanggungjawab dan prestasi belajar peserta didik.

\section{SIMPULAN}

Berdasarkan hasil penelitian ini, dapat disimpulkan bahwa sikap tanggung jawab peserta didik mengalami peningkatan dari siklus I ke siklus II. Ratarata klasikal pada siklus I mencapai 4,04 dengan kriteria ketuntasan baik dan meningkat pada siklus II menjadi 4,30 dengan kriteria ketuntasan sangat baik.Penerapan model pembelajaran 
Numbered Head Together (NHT) berbantu video stop motion dapat meningkatkan prestasi belajar peserta didik. Hal ini dapat dilihat dari prestasi belajar peserta didik yang mengalami peningkatan pada setiap siklus. Prestasi belajar IPA pada siklus I presentase ketuntasan klasikal sebesar $54,16 \%$ dan siklus II yaitu $87,58 \%$. Prestasi belajar Bahasa Indonesiapada siklus I presentase ketuntasan klasikal mencapai $37,5 \%$ dan siklus II yaitu $79,16 \%$.

\section{DAFTAR PUSTAKA}

Arfiah, S. 2001. "Penerapan Metode Kerja Kelompok Untuk Meningkatkan Hasil Belajar IPA Siswa Kelas V SD Negeri 004 Tembilahan Kecamatan Tembilahan". Jurnal Primary. Vol.6, No.(1).

Hidayati, T. R. 2015. "Implementasi Pengembangan Kurikulum 2013 Dalam Pembelajaran Pendidikan Agama Islam dan Budi Pekerti di SMA 4 Negeri Jember". Jurnal Fenomena. Vol,14. No.(1).

Isjoni. 2011. Cooperative Learning: Mengembangkan Kemampuan Belajar Berkelompok. Bandung: Alfabeta.

Mustari, M. 2017. Nilai Karakter Refleksi Untuk Pendidikan. Jakarta: PT Raja Grafindo Persada.
Novelia, dkk. 2017. "Penerapan Mastery Learning Berbantuan LKPD Untuk Meningkatkan Hasil Belajar Tematik Peserta Didik di Kelas VIII. 3 SMP Negeri 4 Kota Bengkulu". Jurnal Penelitian Pembelajaran Matematika Sekolah (JP2MS). Vol.1, No.(1).

Qamariah, dkk. 2017. "Kelayakan Animasi Stop Motion Pembuatan Cake Pepaya Submateri Peran Tumbuhan di Bidang Ekonomi”. Jurnal Pendidikan Matematika dan Sains. Vol. 6, (2).

Slavin, R. 2009. Cooperative Learning: Teori, Riset dan Praktik. Bandung: Penerbit Nusa Media.

Vitoria, L \& Akhwilla, V. "Penerapan Model Pembelajaran Kooperatif Tipe NHT untuk Meningkatkan Hasil Belajar Siswa Pada Materi Pecahan di Kelas V SDN 2 Banda Aceh". Jurnal Pesona Dasar. Vol. 6. No. (2).

Yusuf. W. F. 2018. "Implementasi Kurikulum 2013 (K-13) Pada Mata Pelajaran Pendidikan Agama Islam Sekolah Dasar (SD)". Jurnal Pendidikan Agama Islam. Vol, 3. No.(2). 